\title{
New Perspectives for the Control of Parasitic Diseases Through the Use of Photodynamic Products
}

\author{
Gilmar Sidnei Erzinger* \\ Faculty of Medicine and Pharmacy, University of Joinville Region - UNIVILLE, Joinville, Brazil
}

\begin{abstract}
Parasitic diseases such as malaria, dengue or Schistosomiasis are a plague for millions of people mainly in underdeveloped and developing countries and often prohibit the economic development of the affected areas [19]. Great efforts have been made in the past to extinct or at least control these diseases by means of medical treatment, pesticides, converting wetland etc. - but with limited success. An example of this fact is the epidemic of dengue in Brazil, more specifically in the state of Rio de Janeiro and yellow fever in the center west region of Brazil. An important problem of underdeveloped areas suffering from parasitic diseases is the poverty, which cuts off the supply with material necessary for countermeasures. In the frame of this project we intend to develop methods for pest control, which are very inexpensive and non-toxic and by this are also applicable for poor regions in the world which are infested by severe tropical diseases. The method of pest control is based on the action of photodynamic substances. In contrast to previous attempts we will use inexpensive natural substances which can easily be extracted from plants, such as chlorophylls and their derivatives. Chlorophyll does not show any toxicity in humans: chlorophyll is a colorant in the food industry (E-140/E-141).
\end{abstract}

Keywords: Chlorophyll; Parasitic diseases; Photodynamic substances; Malaria; Dengue; Mosquitos

\section{Research in pest control by means of photodynamic substances}

Experiments conducted with photodynamic substances yielded very promising results. In a recent work performed by Abdel-Kader et al. [10] it was demonstrated that larvae of Culex are sensitive against hematoporphyrine $(0.07 \mu \mathrm{mol} / \mathrm{ml})$. Also larvae of Musa domestica could be killed with this substance $(10 \mu \mathrm{mol} / \mathrm{ml})$. In the course of his $\mathrm{PhD}$ thesis Allah el Tayeb, [11] could demonstrate the effectiveness of hematoporphyrine against Culex and eggs of the snail Lymnea natalensis (vector of the trematode Fasciola hepatica). In this work the penetration of the photosensitizer inside the organism was shown by means of fluorescence microscopy as well as the pronounced effects on the ultrastructure of inner organs and muscles $[10,11]$.

Wohllebe et al. [12], under laboratory conditions, the use of chlorophyllin/pheophorbid as photodynamic substances for pest control in water bodies promises to be not only effective and ecologically beneficial but also cheap. The $\mathrm{LD}_{50}$ ( $50 \%$ of mortality in the tested organisms) value in Culex sp. larvae was about $6.88 \mathrm{mg} / \mathrm{l}$, in Chaoborus sp. larvae about $24.18 \mathrm{mg} / \mathrm{l}$, and in Daphnia $0.55 \mathrm{mg} / \mathrm{l}$. The $\mathrm{LD}_{50}$ values determined for pheophorbid were $8.44 \mathrm{mg} / \mathrm{l}$ in Culex, $1.05 \mathrm{mg} / \mathrm{l}$ in Chaoborus, and $0.45 \mathrm{mg} / \mathrm{l}$ in Daphnia, respectively. In some cases, chlorophyllin and pheophorbid were also found to be (less) active in darkness. The results presented in this paper show that chlorophyllin is about a factor of 100 more effective than methylene blue or hematoporphyrine, which were tested earlier for the same purpose. It is also much cheaper and, as a substance found in every green plant, it is $100 \%$ biodegradable.

Erzinger et al. [13] was demonstrated that mosquito larvae can be killed by means of photodynamic processes after the larvae have incorporated the photosensitizer chlorophyllin or pheophorbid, and were treated with light. The water-soluble substances were applied to and incorporated by the larvae in darkness. With Chaoborus sp. a dark incubation of about $3 \mathrm{~h}$ is sufficient to yield mortality of about $90 \%$ and $\geq 6$ h resulted in almost $100 \%$ mortality during subsequent illumination. Temperature did not influence mortality of the larvae significantly in a treatment of $6 \mathrm{~h}$ dark incubation and subsequent 3 h illumination. At $10^{\circ} \mathrm{C}, 20^{\circ} \mathrm{C}$, or $30^{\circ} \mathrm{C}$, between $80 \%$ and $100 \%$ of the treated larvae died when the light intensity from a solar simulator was above $30 \mathrm{~W} / \mathrm{m}^{2}$. Lower irradiances were less effective.

Wohllebe et al. [14] have demonstrated for the first time that the photodynamic treatment of C. crystallinus larvae with chlorophyllin induces necrosis and apoptosis in these organisms. The intrinsic pathway of apoptosis plays a key role in this model.

\section{Preservation of photodynamic activity of chlorophyllin}

Erzinger et al. [13] described a major problem for the use of chlorophyll and its derivatives are related allomerization reactions. Allomerized chlorophyll a differs from the original material in that the product of hot alkaline hydrolysis is a mixture of unstable chlorins instead of the initial product chlorin. The same unstable chlorins are obtained from unallomerized chlorophyll or the magnesium-free compounds (pheophytin a or methyl pheophorbide a by saponification with alcoholic alkali at or below room temperature). Allomerization of chlorins is a dehydrogenation caused by oxygen of the air. It is

${ }^{*}$ Corresponding author: Dr. Gilmar Sidnei Erzinger (Ph.D. in Biochemistry Pharmaceutical Technology), Department of Medicine and Pharmacy, Masters Program in Health and Environment, University of Joinville Region - UNIVILLE, Campus Universitario S / N, Joinville, SC - CEP 89223-251, Brazil, Tel: 47 3461-9152; E-mail: gerzinger@univille.br

Received August 01, 2011; Accepted November 08, 2011; Published November 10, 2011

Citation: Erzinger GS (2011) New Perspectives for the Control of Parasitic Diseases Through the Use of Photodynamic Products. Pharm Anal Acta 2:139. doi:10.4172/2153-2435.1000139

Copyright: (C 2011 Erzinger GS. This is an open-access article distributed under the terms of the Creative Commons Attribution License, which permits unrestricted use, distribution, and reproduction in any medium, provided the original author and source are credited. 


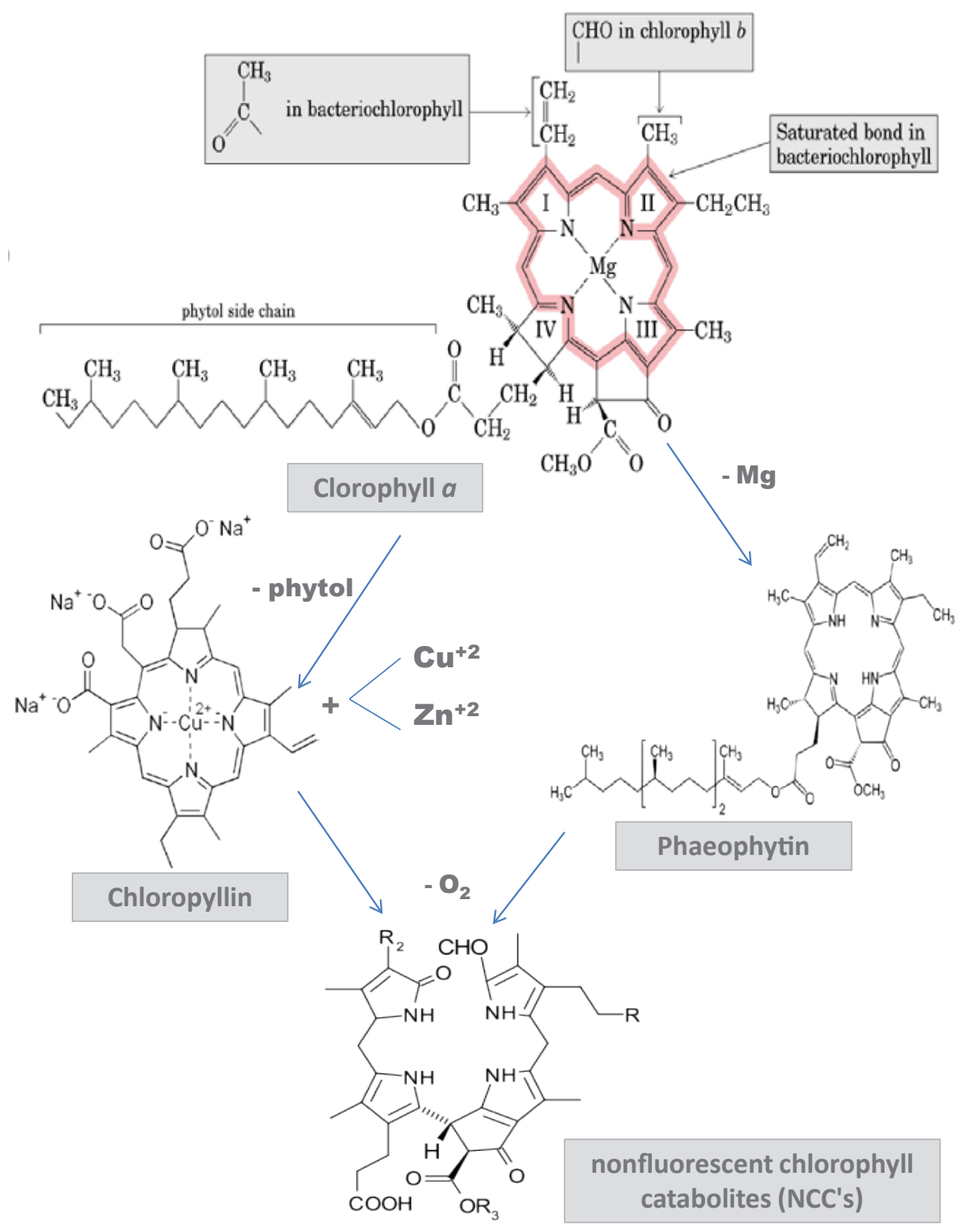

Figure 1: Chlorophyll and metabolic derivates

interesting that the dehydrogenation of a very easily oxidizable group in chlorophyll is without pronounced effect on its color, although marked color changes, as a rule, accompany the oxidation of colored substances. The unusual behavior of chlorophyll in this respect is due to the fact that the chromophoric group is not the most easily oxidized group [15-17] (Figure 1).

One of the alternatives considered were to make structural changes in chlorophyll derivatives by substitution of magnesium or in the process of conservation. The $\mathrm{LD}_{50}$ value of magnesium chlorophyllin was about $22.25 \mathrm{mg} / \mathrm{l}$ and for $\mathrm{Zn}$ chlorophyll $17.53 \mathrm{mg} / \mathrm{l}$, while $\mathrm{Cu}$ chlorophyll $\left(\mathrm{LD}_{50} 0.1 \mathrm{mg} / \mathrm{l}\right)$ was shown to be toxic also without light. Chlorophyllin, which was lyophilized immediately after extraction, was far more lethal to the larvae $\left(\mathrm{LD}_{50} 14.88 \mathrm{mg} / \mathrm{l}\right)$ than air-dried $\mathrm{Mg}$ chlorophyllin.Lyophilization immediately after isolation increases photodynamic activity of chlorophyllin and ensures its long-term stability [13].

\section{Development of a new product}

In 2010 Erzinger and Häder [18] developed and patented at INPI (National Institute of Intellectual Property) a new Bioinsecticide Nontoxic Biodegradable from a new semi-synthetic derivative of chlorophyll and in conjunction with a formulation system was able to get a product with high stability front light and maintained the same lethal power of chlorophyll and chlorophyllin for mosquito 
Citation: Erzinger GS (2011) New Perspectives for the Control of Parasitic Diseases Through the Use of Photodynamic Products. Pharm Anal Acta 2:139. doi:10.4172/2153-2435.1000139

larvae described in previous work. Currently is being done to study the possible environmental impacts of the continued use of this new product.

\section{Conclusions and Perspectives}

The derivates of chlorophyll is a very interesting substance for photodynamic pest control. For this reason we conducted some primarily experiments in which we tested the effects on larvae of Chaoborus and Culex flies. We extracted chlorophyll from different plant sources (spinach, grass, dandelion etc.). Some experiments we conducted with chlorophyll converted into pheophytin or into a watersoluble chlorophyllide. We have developed a cheap new strategy for reducing the number of mosquito larvae, which may be very important for reducing the amount of mosquito bites and thereby the incidence of malaria and other parasitic diseases in the future.

\section{Acknowledgements}

Prof. Dr. Donat Peter Häder is a postdoctoral research fellow of the FAU. The several studies presented in this paper were financially supported by Research Support Fund of UNIVILLE and DAAD, Germany. Dr. P. Richter, Department of Biology, Cell Biology, Friedrich-Alexander-University Erlangen-Nuremberg Germany and S. Wohllebe, Bavarian State Research Centre for Agriculture, Institute for Fisheries, Starnberg, Baden-Württemberg, Germany for the fruitful collaboration.

\section{References}

1. Drovetta RI, Eynard M (2011) La construcción de metáforas y adjetivaciones sobre la enfermedad en la prensa escrita: el caso de la epidemia de dengue en Córdoba durante abril de 2009. Saude soc 20: 241-256.

2. Zambrini DAB (2011) Lecciones desatendidas entorno a la epidemia de dengue en Argentina, 2009. Rev Saúde Pública 45: 428-431.

3. Maciel-de-Freitas R, Lourenço-de-Oliveira R (2009) Presumed unconstrained dispersal of Aedes aegypti in the city of Rio de Janeiro, Brazil. Rev Saúde Pública 43: 8-12.

4. González Fernández MI, Orozco Núñez E, Cifuentes E (2010) Policy analysis of the dengue control program in Mexico. Rev Saúde Pública 44: 1079-1086.

5. Degallier N, Favier C, Boulanger JP, Menkes C (2009) Imported and autochthonous cases in the dynamics of dengue epidemics in Brazil. Rev Saúde Pública 43: 1-7.
6. Sabbatani S, Manfredi R, Fiorino S (2010) Malaria infection and the anthropological evolution. Saude soc 19: 64-83.

7. Parise ÉV, Araújo GC, Castro JG, Berdarrain FP (2011) Epidemiological profile of malaria in the state of Tocantins, Brazil, from 2003 to 2008. Rev Inst Med trop S Paulo 53: 141-147.

8. Scuracchio P, Vieira SD, Dourado DA, Bueno LM, Colella R, et al. (2011) Transfusion-transmitted malaria: case report of asymptomatic donor harboring Plasmodium malariae. Rev Inst Med trop S Paulo 53: 55-59.

9. Inoue J, Machado CM, Lima GF, Nascimento Mde J, Colturato VR, et al. (2010) The monitoring of hematopoietic stem cell transplant donors and recipients from endemic areas for malaria. Rev Inst Med trop S Paulo 52: 281-284.

10. Abdel-Kader MH, Al-Sherbini ASAM, El Tayeb TAA (1999) 8-Sunlight and photosensitizers for insect control. The 9th International Conference on "Environmental Protection is a must," Alexandria University, May 4-6.

11. El Tayeb TAA (2003) Laser scanning microscopy for determination of the efficiency of hematoporphyrin in control of Culex pipiens larvae and the snail vector of Fasciola gigantica. PhD thesis. National Institute of Laser Enhanced Sciences (NILES), Cairo University 1-216.

12. Wohllebe S, Richter R, Richter P, Häder DP (2009) Photodynamic control of human pathogenic parasites in aquatic ecosystems using chlorophyllin and pheophorbid as photodynamic substances. Parasitol Res 104: 593-600.

13. Erzinger GS, Wohllebe S, Vollrath F, Souza SC, Richter P, et al. (2011) Optimizing conditions for the use of chlorophyll derivatives for photodynamic control of parasites in aquatic ecosystems. Parasitol Res 109: 781-786.

14. Wohllebe SC, Ulbrich D, Grimm J, Pietsch G, Erzinger R, et al. (2011) Photodynamic Treatment of Chaoborus crystallinus larvae With Chlorophyllin Induces Necrosis and Apoptosis. Parasitol Res 104: 593-600.

15. Conant JB, Kamerling SE, Steele CC (1931) The allomerization of chlorophyll J Am Chem Soc 53: 1615-1616.

16. Kupper H, Spiller M, Kupper FC (2000) Photometric method for the quantification of chlorophylls and their derivatives in complex mixtures: fitting with Gausspeak spectra. Anal Biochem 286: 247-256.

17. Woolley PS, Moir AJ, Hester RE, Keely BJ (1998) A comparative study of the allomerization reaction of chlorophyll a and bacteriochlorophyll a. J Chem Soc Perkin Trans 2: 1833-1893.

18. Erzinger GS, Häder DP (2009) Bioinsecticide Nontoxic Biodegradable from UNIVILLE. National Institute of Intellectual Property - INPI. Nº. 020090120220 